\title{
«ЛЕТАЮЩИЕ ГРОБЫ»? К ВОПРОСУ ОБ ИСПОЛЬЗОВАНИИ ДРЕВЕСИНЫ В СОВЕТСКОМ САМОЛЕТОСТРОЕНИИ В ПЕРИОД ВЕЛИКОЙ ОТЕЧЕСТВЕННОЙ ВОЙНЫ
}

\author{
М. В. Шерстюк \\ (Российский государственный аграрный университет - \\ МСХА им. К. А. Тимирязева)
}

Аннотация: В статье рассматриваются некоторые проблемы отечественного самолетостроения в годы Великой Отечественной войны. Называются причины и обоснованность использования в авиастроении заменителей металла: древесины и тканей; проводится сравнение с аналогичной практикой зарубежных стран.

Подготовлено на основе доклада автора на Всероссийской научной конференции «Военная история России», которая прошла в Московском гуманитарном университете 25 апреля 2016 г.

Ключевые слова: Великая Отечественная война; история войн; военная авиация; самолетостроение; бомбардировщик; истребитель

\section{«FLYING COFFINS»? ON THE USE OF WOOD IN SOVIET AIRCRAFT CONSTRUCTION DURING THE GREAT PATRIOTIC WAR}

\author{
M. V. Sherstyuk \\ (Russian State Agrarian University - MTAA)
}

Abstract: The article examines several problems of the Russian aircraft engineering during the war, primarily the reasons for using metal substitutes (wood and fabric) in aircraft industry. Also provided is the comparative analysis of analogous practices in other countries.

This article is based on the paper presented at "The military history of Russia" conference, which was held at Moscow University for the Humanities on April 25, 2016

Keywords: Great Patriotic war; history of warfare; military aircraft; aircraft construction; bomber; fighter plane

В советской литературе, посвященной Великой Отечественной войне, общим местом было весьма хвалебное отношение к отечественной военной технике: «лучший танк Второй мировой» - Т-34, лучшая пушка - ЗИС-3, лучший штурмовик - ИЛ-2, лучший истребитель - ЯК-3 (см. напр.: История Второй ..., 1973-1982). 
В конце 1980-х и в 1990-е гг. на волне перестройки и последующего развенчивания советской истории оценки сменились на противоположные. Стало модным поливать грязью как советских воинов, так и советскую тех-нику. Не обошел стороной этот процесс и авиацию. Сразу всплыла и многократно растиражировалась реплика начальника Главного управления ВВС Красной Армии генерал-лейтенанта П. В. Рычагов, брошенная И.В. Сталину на Главном военном совете в начале апреля 1941г. на котором рассматривались причины высокой аварийности в ВBC: «Вы заставляете нас летать на гробах, а потом упрекаете в высокой аварийности» (Решетников, 2007: 179).

Эти «летающие гробы», помноженные на совершенно фантастические цифры побед немецких «асов» на восточном фронте (Спик, 2003: 325), стали настоящим приговором советской авиации, вынесенном «демократической» постсоветской прессой. Ну, а то, что СССР по какому-то недоразумению все-таки победил Германию, так это «трупами завалил», а хребет фашистскому зверю якобы сломали его союзники.

Хотелось бы отойти от таких явно политизированных оценок и спокойно и объективно разобраться в непростых вопросах военной истории. И вопрос о качестве, а точнее, о технологии производства советской авиационной техники нам кажется важным и актуальным.

Одним из основных аргументов «развенчателей» советской авиационной техники служит тот факт, что в производстве самолетов широко использовался такой материал, как дерево и его производные (поэтому, собственно, и «гробы»). Давайте же попробуем разобраться: какую роль играло дерево в авиации периода Второй мировой войны, как советской, так и других стран участниц?

Действительно, в производстве большинства боевых советских самолетов довоенного и военного периодов широко использовалось дерево, да и не только дерево, но и ткань, и казеиновый клей, и другие материалы. Из древесины изготовлялись элементы конструкции крыла, фюзеляжа, хвостовое оперение, винт. Использовался как массив дерева, так и фанера. Из пород - береза, сосна, ясень, лиственница и др.

Применение дерева в самолетостроении имеет давнюю историю и связано, в первую очередь, с высокой стоимостью крылатого металла алюминия и его производных и борьбой за облегчение конструкции.

В Советском союзе выпускались боевые самолеты как смешанной конструкции (например, семейство ЯКов), как и полностью деревянные (самолеты Лавочкина). По своим летно-техническим характеристикам они были на уровне самолетов противника и союзников, а по мере развития промышленности и техники и доводке, прежде всего, ВМГ, стали превосходить лучшие модели иностранных государств (Ла-7 и Ла-9, Як-9 
и Як-3) (Мерников, 2005: 472, 489-491).

В условиях войны главной задачей авиационной промышленности был выпуск возможно большего числа самолетов. К ним предъявлялись довольно умеренные требования в отношении удобства эксплуатации, качества изготовления, срока службы и т. п.

Смешанная конструкция была рациональной и целесообразной в условиях войны, когда ощущался недостаток в дюрале. Благодаря простоте и технологичности она обеспечивала массовость производства и полное удовлетворение потребностей фронта.

Наряду с этим она обладала такими недостатками, как сравнительно малый срок службы, подверженность воздействию атмосферных и других неблагоприятных условий эксплуатации, быстрая потеря прочности и ухудшение аэродинамики, а, следовательно, и летных качеств, особенно снижение максимальной скорости.

Одной из распространенных ошибок является утверждение, что деревянные самолеты горели как свечки. Наоборот, самолеты с деревянными элементами конструкции отличались высокой степенью живучести. Например, был случай благополучного возвращения самолета ЯК-7 на свой аэродром, когда был разбит правый элерон, вырван кусок плоскости с обшивкой и нервюрами до элеронов; сорван носок крыла до переднего лонжерона; снесена полотняная обшивка руля поворота и со всей боковины фюзеляжа; отбита половина консоли стабилизатора и часть руля высоты; пробита тяга управления посадочными щитками. Самолет производил посадку с одним выпущенным и одним свободно висевшим щитком; многократно пробиты пояса лонжеронов, тяги элеронов и другие жизненно важные конструктивные элементы (ЯК-7А, Электр. ресурс).

Однако целесообразность более широкого использования металла в конструкции планера никто под сомнение не ставил. Постоянное увеличение скоростей и нагрузок неизбежно требовало пересмотра устоявшихся схем строения самолета. Скажем, при создании конструкторским бюро А. С. Яковлева самолета Як-9У (улучшенный), последней и наиболее совершенной во всех отношениях модификация Як-9, полотняная обшивка фюзеляжа была заменена на фанерную, толщиной 2 мм (Якубович, 2008: 66).

Переход к производству металлических самолетов происходит постепенно в ходе войны, по мере изживания дефицита в дюрале. Первым шагом явилось создание в 1942 г. Як-7ДИ - прототипа Як-9, у которого деревянные лонжероны с очень толстыми и тяжелыми полками - таврами - были заменены дюралевыми. Затем металлические лонжероны использовали на Як-1М (Як-3). И, наконец, в 1946 г. был создан Як-9П с цельнометаллическим крылом. Кстати говоря, замене дюралевыми подвергались не только деревянные детали, но и стальные. Все дальнейшие 
модификации самолетов в направлении создания цельнометаллических конструкций были связаны с тем, что после окончания войны со стороны заказчика (BBC) к самолетам стали предъявляться более жесткие эксплуатационные требования. Но процесс этот был длительным и очень непростым с инженерно-технической стороны. В связи с неосвоенностью производства металлических самолетов (в основном клепальных работ) и меньшей гладкостью поверхности металлического крыла по сравнению с деревянным летно-тактические характеристики снижались. По сути, только с наступлением эры реактивной авиации советская авиационная индустрия смогла отойти от широкого использования дерева в конструкциях боевых самолетов.

Но в корне неверно было бы думать, что деревянные самолеты - исключительная прерогатива «отсталого советского авиапрома». На западе, как в стане врагов, так и в стане союзников, картина была схожей, что не удивительно, учитывая схожие традиции самолетостроения и схожие про-блемы, стоявшие перед авиаконструкторами.

Вот лишь несколько примеров. Так, английские авиаконструкторы не стеснялись использовать древесину в конструкциях своих самолетов самого разного предназначения. Скажем, на первых серийных «Спитфайрах» стояли двухлопастные деревянные (из махагони - красного дерева) винты. Аналогичными винтами комплектовались и известные «Харрикейны». Деревянными у них были и шпангоуты, и рейки-стрингеры. Выпуск деревянных крыльев прекратили лишь весной 1940 г. (Истребители Второй Мировой, Электр. ресурс). Про цельнодеревянную конструкцию Де Хэвилленд «Москито», который по-лучил прозвище «скоростное деревянное чудо», общеизвестно. Этот самолет в самых разных модификациях (бомбардировщик, ночной истребитель, истребитель-бомбардировщик, разведчик) прошел всю войну. В качестве одного из существенных достоинств машины указывалось, что цельнодеревянная конструкция позволяла задействовать для их производства в качестве субподрядчиков десятки деревообрабатывающих и мебельных предприятий (ВС Великобритании: Электр. ресурс).

В аналогичной ситуации оказалась и высокотехнологичная немецкая авиапромышленность. «Сумрачный тевтонский гений» в условиях нехватки алюминиевых сплавов, особенно в конце воины, был вынужден прибегать ко все более широкому использованию древесины даже в новейших конструкциях реактивных самолетов. Так, уникальный Me.163 Komet, единственный оснащенный жидкостным ракетным двигателем самолетбесхвостка, который был принят на вооружение и участвовал в реальных боях, развивавший рекордную для своего времени скорость и скороподъемность, имел деревянную конструкцию крыла и киля, а руль направления 
с дюралевым каркасом и полотняной обшивкой. Высотный истребитель Me-209HV1 оснащался деревянным 4-х лопастным винтом диаметром 3,4 м. То же можно сказать про средний бомбардировщик Do.217 с его трехлопастным деревянным винтом «Шварц». При конструировании тяжелого истребителя-бомбардировщика Me.410 Hornisse на определенном этапе проектирования в целях экономии перешли на деревянную конструкцию планера (Боевые самолеты люфтваффе, 2004: 38, 222, 445).

Как видим, использование в советской авиапромышленности древесины в разных видах говорит не столько об отсталости или низкой технологичности производства, сколько о готовности и решимости в самых сложных производственно-экономических условиях использовать все имеющиеся в распоряжении страны возможности для укрепления ее обороноспособности и военного потенциала.

\section{СПИСОК ЛИТЕРАТУРЫ}

Боевые самолеты люфтваффе (2004) / под ред. Д. Дональда. М. : Издательство АСТ. 255 с.

ВС Великобритании. Москито истребитель-бомбардировщик. [Электронный ресурс] // Toparmy.ru URL: http://toparmy.ru/armii-istorii/vsvelikobritanii/moskito-istrebitel-bombardirovshhik.html (дата обращения: 18.04.2016).

История Второй мировой войны 1939-1945 гг. : в 12 томах. (19731982) М.: Воениздат.

Истребители Второй Мировой [Электронный ресурс] // Уголок Неба. Большая авиационная энциклопедия. URL: http://www.airwar.ru/ fighterww2.html (дата обращения: 18.04.2016).

Мерников, А. Г. (2005) Армия Победы против вермахта. М. : АСТ ; Мн. : Харвест. 623 с.

Решетников, В. В. (2007) Обреченные на подвиг. М. : Яуза, Эксмо. 320 с.

Спик, М. (2003) Асы люфтваффе. Смоленск : Русич. 431 с.

ЯК-7А [Электронный ресурс] // Уголок Неба. Большая авиационная энциклопедия. URL: http://www.airwar.ru/enc/fww2/yak7a.html (дата обращения: 18.04.2016)

Якубович, Н. В. (2008) Истребитель Як-9. Заслуженный «фронтовик». М. : Коллекция ; Яуза ; ЭКСМО. 118 с.

Дата поступления: 15.06.2016 г. 
Шерстюк Максим Витальевич - кандидат исторических наук, доцент кафедры истории Гуманитарно-педагогического факультета Российского государственного аграрного университета - МСХА им. К. А. Тимирязева. Адрес: 127550, Россия, г. Москва, ул. Верхняя аллея, д. 4а. Тел.: +7 (499) 976-18-52. Эл. адрес: history@timacad.ru

Sherstyuk Maxim Vitalievich, Candidate of History, Associate Professor, Department of History, Faculty of Humanities and Education, Russian State Agrarian University - MTAA. Postal address: 4a Verhnyaya alleya, 127550 Moscow, Russian Federation. Tel.: +7 (499) 976-18-52. E-mail: histo-ry@ timacad.ru 